\title{
How to Report Receivables at Fair Value?
}

\author{
Damito D. Magpantay \\ Student, De La Salle University \\ 2401 Taft Avenue, 1004 Manila, Philippines \\ Tel: 632-646-0566 E-mail: magpantay.damito@gmail.com
}

Received: April 18, 2013 Accepted: May 07, 2013 DOI: 10.5296/ijafr.v3i1.3710

\begin{abstract}
The problem of asymmetric information faced by creditor-firms arising from deceitful manipulation of credit information by debtor-firms lingers because current disclosure standards fail to capture relevant information about the measure of creditworthiness of debtor-firms.
\end{abstract}

Keywords: asymmetric information, credit score, credit risk, receivables 


\section{Mll Macrothink}

International Journal of Accounting and Financial Reporting

ISSN 2162-3082

2013, Vol. 3, No. 1

\section{Introduction}

An effective way to persuade clients to buy goods or avail of services is for a business entity to allow the use of credit to facilitate sale transactions. This holds true for any firm wanting to capture a bigger share of the market.

Compared to a rival firm who exclusively transacts in cash, a business entity who permits its customers to buy goods or avail of services on credit - is more likely to generate higher revenues. This is because the option of buying goods on credit permits the business entity to attract an entirely different and wider client-base - to include customers with limited capacity to spend due to inadequate cash.

Debtor-firms with limited financial resources however cannot expand their businesses without availing of some form of financial assistance from creditor-firms. As firms are left to pursuit their profit motives, they become more passive about the level of risks they are taking. As a result, firms render themselves susceptible to the problem of asymmetric information.

\section{Methodology}

In addressing the problem of information asymmetry, it was necessary to dwell substantially on how debtor-firms and creditor-firms behaved in real life. To ensure partiality throughout this research, microeconomic theories and tools were used to support claims explaining the behaviour of debtor-firms and creditor-firms.

This research paper starts with a discussion of how creditor-firms manage credit risks (Section 3). Shortly thereafter, Section 4 follows with an overview of the process of applying for credit. Sections 5 through 7 cover an in-depth analysis of the behaviour of creditor-firms. Section 8 illustrates the problem of asymmetric information and discusses about a proposed solution to the problem of information asymmetry.

\section{Managing Credit Risks}

Undoubtedly, offering credit terms to customers helps firms address their concern about how to increase their sales turnover ${ }^{1}$. However, such a change in approach does nothing to reduce the overall business risk $^{2}$ faced by the firm.

\footnotetext{
${ }^{1}$ Sales turnover represents the value of goods and services provided to customers during a specified time period - usually one year.

- The term is often just referred to as sales or net sales, which means revenues without value added tax (VAT).

- Sales turnover is usually expressed in monetary terms but can also be in total units of stock or products sold.

- It is often described by being converted into the company's accounting currency. http://www.e-conomic.co.uk/accountingsystem/glossary/sales-turnover

2 It refers to the possibility that a company will have lower than anticipated profits, or that it will experience a loss rather than a profit. Business risk is influenced by numerous factors, including sales volume, per-unit price, input costs, competition, overall economic climate, and government regulations. A company with a higher business risk should choose a capital structure that has a lower debt ratio to ensure that it can meet its financial obligations at all times. http://www.investopedia.com/terms/b/businessrisk.asp
} 
This is because selling on credit only results to a transformation of the kind of risk(s) the firm is exposed to. From where there used to be a sales risk ${ }^{3}$, the company is now confronted with credit risks ${ }^{4}$.

\section{Applying for Credit}

Buying on credit though is not guaranteed. The use of credit is a privilege extended by the seller-creditor and not an inherent right of the buyer-debtor. That is why buyer-debtors must apply for the privilege of using credit and undergo a credit rating process 5 .

The end result of the credit rating process will be an objective assessment of the likelihood that the buyer-debtor will incur default ${ }^{6}$. The credit rating process does not indicate a specific probability of default over any given time period.

In the determination of the credit score $^{7}$ (also called credit rating), seller-creditors typically consider several factors from the buyer-debtor's credit report.

\begin{tabular}{|c|c|}
\hline Factors in Credit Score & Weight \\
\hline 1. Payment History & $35 \%$ \\
\hline 2. Amounts Owed & $30 \%$ \\
\hline 3. Length of credit history & $15 \%$ \\
\hline 4. Types of credit in use & $10 \%$ \\
\hline 5. New Credit & $10 \%$ \\
\hline Total & $100 \%$ \\
\hline
\end{tabular}

Source: What's in my FICO Score, http://www.myfico.com/CreditEducation/WhatsInYourScore.aspx

\footnotetext{
${ }^{3}$ It is the uncertainty with respect to the quantity of goods and services that a company is able to sell and the price it is able to achieve; the risk related to the uncertainty of revenues. http://likeforex.com/glossary/w/sales-risk-46083

${ }^{4}$ Credit risk is defined as the risk of loss of principal or loss of a financial reward stemming from a borrower's failure to repay a loan or otherwise meet a contractual obligation. Credit risk arises whenever a borrower is expecting to use future cash flows to pay a current debt. Investors are compensated for assuming credit risk by way of interest payments from the borrower or issuer of a debt obligation. http://www.investopedia.com/terms/c/creditrisk.asp
}

\footnotetext{
${ }^{5}$ A credit rating is a formal evaluation of an individual's or a company's credit history and ability to repay obligations. A credit rating therefore assesses the creditworthiness of an applicant. The term 'credit rating process' is used to describe the methodologies used by banks to determine the credit rating of a loan applicant. http://www.ibf.ie/Libraries/Guides_Forms/Credit_Rating_Process_web.sflb.ashx

${ }^{6}$ It is the failure to promptly pay interest or principal when due. Default occurs when a debtor is unable to meet the legal obligation of debt repayment. Borrowers may default when they are unable to make the required payment or are unwilling to honor the debt. http://www.investopedia.com/terms/d/default2.asp
}

7 A credit score is a numerical summary of the information contained in your credit report. Credit scores typically range from 300 to 850 with higher credit scores being better. Your credit score is calculated based on the information in your credit report. The more negative information in your credit report, the lower your credit score will be. The six worst credit report entries include charge-offs, debt collections, bankruptcy, foreclosure, tax liens, and judgments. Many creditors, lenders, and other businesses use your credit score to make a quick decision about approving your application or giving you a competitive interest rate. credit score By LaToya Irby, About.com Guide, http://credit.about.com/od/glossary/g/creditscore.htm 


\section{Macrothink}

Mathematically, credit scores $\left(\mathrm{S}_{\mathrm{C}}\right)$ can be shown as

$\mathbf{S}_{\mathrm{C}}=\mathbf{f}\left(\mathbf{P}_{\mathrm{H}}, \mathbf{A}_{\mathbf{O}}, \mathbf{L}_{\mathbf{C H}}, \mathbf{C}_{\mathrm{T}}, \mathbf{C}_{\mathrm{N}}, \mathbf{W}_{\mathrm{D}}\right)$ where

$\Rightarrow \mathrm{P}_{\mathrm{H}}$ refers to payment history,

$\Rightarrow \mathrm{A}_{\mathrm{O}}$ refers to amounts owed,

$\Rightarrow \mathrm{L}_{\mathrm{CH}}$ refers to length of credit history,

$\Rightarrow \mathrm{C}_{\mathrm{T}}$ refers to types of credit in use,

$\Rightarrow \mathrm{C}_{\mathrm{N}}$ refers to new credit, and

$\Rightarrow \mathrm{W}_{\mathrm{D}}$ refers to the weight distribution of factors considered in the determination of the credit score

Generally, credit scores do not consider the following factors:

- Your race, color, religion, national origin, sex and marital status.

- Your age.

- Your salary, occupation, title, employer, date employed or employment history.

- Where you live.

- Any interest rate being charged on a particular credit card or other account.

- Any items reported as child/family support obligations or rental agreements.

- Certain types of inquiries.

- Any information not found in your credit report.

- Any information that is not proven to be predictive of future credit performance.

- Whether or not you are participating in a credit counselling of any kind. ${ }^{8}$

But ratings are opinions about risk, not formulas. Accurate, forward-looking credit analysis cannot be mechanized. ${ }^{9}$

In spite of what credit scores may represent, these do not ensure credit approval. At best, an excellent credit score only gives the buyer-debtor a better-than-average chance of getting his/her request for credit line approved.

Evidently, the decision of the seller-creditor is not purely motivated by the risk (that is, $\mathrm{r}=\mathrm{R}\left(\mathrm{S}_{\mathrm{C}}\right)=1-\mathrm{S}_{\mathrm{C}}$ associated with the credit score. Rather the seller-creditor is encouraged to decide favourably on a request for credit line because of potential profits.

\footnotetext{
${ }^{8}$ What's not in my FICO Score, http://www.myfico.com/CreditEducation/WhatsNotInYourScore.aspx

9 The Same Rating from Different Agencies Only Looks the Same, Understanding Risk, About Moody's Ratings, http://www.moodys.com/ratings-process/Same-Rating-Different-Agencies-Only-Looks-the-Same/002004002
} 
As to why $r=R\left(S_{C}\right)=1-S_{C}$ will be explained thoroughly in the succeeding sections.

\section{Making profits}

It's all about PROFIT, not RISK

Lenders aren't obliged to dole out credit. Instead, decisions revolve around how much money you're likely to make them. This means savvy customers who always repay in full, or shift debt to $0 \%$ cards to avoid interest, may get rejected as the bank'll make no money!

Risk plays a part, as those unlikely to repay are a threat to profits. But banks exist to make money. Grasp that and you can play the system. ${ }^{10}$

Let us consider the case of banks and other financial intermediaries.

As lenders of money, interest income from loans account for bulk of their revenues. Recall from investment mathematics that interest income $\left(\mathrm{I}_{\mathrm{L}}\right)$ is a function based on principal amount $\left(\mathrm{P}_{\mathrm{A}}\right)$, interest rate $\left(\mathrm{I}_{\mathrm{R}}\right)$ and term of the loan $\left(\mathrm{T}_{\mathrm{L}}\right)$ such that

$\mathbf{I}_{\mathrm{L}}=\mathbf{f}\left(\mathbf{P}_{\mathrm{A}}, \mathbf{I}_{\mathbf{R}}, \mathbf{T}_{\mathrm{L}}\right)=\mathbf{P}_{\mathrm{A}} \times \mathbf{I}_{\mathbf{R}} \times \mathbf{T}_{\mathrm{L}}$

It is assumed in this research that the interest rate on loans $\left(I_{R}\right)$ could either be a floating interest rate $^{11}\left(\mathrm{I}_{\mathrm{V}}\right)$ or fixed interest rate ${ }^{12}\left(\mathrm{I}_{\mathrm{F}}\right)$. That is, $\mathbf{I}_{\mathbf{R}}=\mathbf{I}_{\mathbf{V}}$ or $\mathbf{I}_{\mathbf{R}}=\mathbf{I}_{\mathbf{F}}$.

$\mathbf{I}_{\mathbf{V}}=\mathbf{f}\left(\mathbf{M}, \mathbf{T}_{\mathbf{L}}, \mathbf{R}_{\mathbf{B}}\right)$ where

$\Rightarrow \mathrm{M}$ refers to the margin or spread added to some base rate and is a function of risk, $r$ (that is, $M=f(r)$ ),

$\Rightarrow \mathrm{T}_{\mathrm{L}}$ refers to the term of the loan, and

$\Rightarrow R_{B}$ refers to the base such as the prime lending rate.

$\mathbf{I}_{\mathbf{F}}=\mathbf{f}\left(\mathbf{M}, \mathbf{R}_{\mathbf{D}}\right)$ where

$\Rightarrow \mathrm{M}$ refers to the margin or spread added to some base rate and is a function of risk, $r$ (that is, $M=f(r)$ ), and

$\Rightarrow R_{D}$ refers to the lender's assumption(s) about the average discount rate over a fixed rate period.

As to why $\mathrm{M}=\mathrm{f}(\mathrm{r})$ will be explained thoroughly in the succeeding sections.

\section{Risk Appetite}

Like any other investor, creditor-firms try to strike the proper balance of risks and profits when deciding to whom credit is extended to.

\footnotetext{
10 Credit Rating, How it works and how to improve it, http://www.moneysavingexpert.com/loans/credit-rating-credit-score\#know

11 Floating interest rate, http://en.wikipedia.org/wiki/Floating_interest_rate

12 Fixed interest rate, http://en.wikipedia.org/wiki/Fixed interest
} 


\section{Mll Macrothink}

International Journal of Accounting and Financial Reporting

ISSN 2162-3082

2013, Vol. 3, No. 1

Creditor-firms who steer clear from risks are benefitted with only average returns on their investments whereas creditor-firms who enjoy taking risks are rewarded with above average returns on their investments. The foregoing statement complies with the rule of thumb which states that "the higher the risk, the higher the potential return".

Evidently, the rule of thumb as stated above is incomplete. If such were truly the case in real life, all creditor-firms face an obvious choice and that is, to grant credit to the debtor-firm tagged with the highest of credit scores or lowest of risk of default ratings.

What is missing from the rule of thumb as stated above is that it fails to account for the odds of realizing the higher return. Therefore, the rule of thumb as stated above should be revised to read as "the higher the risk, the higher the potential return, and the less likely it will achieve the higher return"13.

The revised rule of thumb "the higher the risk, the higher the potential return and the less likely it will achieve the higher return" can mathematically be expressed as

$I_{V}=\mathbf{f}\left(M, T_{L}, R_{B}\right)=\mathbf{f}\left(\mathbf{f}(\mathbf{r}), T_{L}, R_{B}\right)$ since $M=f(r)$ and

$I_{F}=\mathbf{f}\left(M, R_{D}\right)=\mathbf{f}\left(\mathbf{f}(\mathbf{r}), \mathbf{R}_{\mathbf{D}}\right)$ since $M=\mathbf{f}(\mathbf{r})$

Since creditor-firms differ from one another in terms of risk appetite ${ }^{14}$, it follows that each creditor-firm behaves differently around credit scores.

Risk-averse creditor-firms may not be willing to take a chance on debtor-firms with low credit scores whereas risk-taking creditor-firms may tend to do otherwise. Risk-taking creditor-firms are expected to behave this way because the low credit score under consideration fell within its risk appetite.

The same applies to debtor-firms possessing high credit scores. For as long as the high credit score falls outside of a creditor-firm's risk appetite, credit approval will be unlikely. At first, this may seem counter-intuitive but the contrary has its merits.

Recall that creditor-firms make the decision to grant credit on the basis of risks and profits. Any profit-seeking creditor-firm is likely to shun away from debtor-firms with high credit scores simply because they cannot charge any higher than they could have if faced with a debtor-firm with a considerably lower credit score. Thus, the potential for profit is limited with debtor-firms owning high credit scores.

To illustrate, let us consider the following graph to appreciate more the ramifications of risk appetite on risks and profits.

\footnotetext{
13 Understanding Risk, Risk and Reward are Part of Investing By Ken Little, About.com Guide, http://stocks.about.com/od/riskreward/a/Understandrisk.htm

${ }^{14}$ Risk appetite is the amount of risk, on a broad level, an organization is willing to accept in pursuit of value. Each organization pursues various objectives to add value and should broadly understand the risk it is willing to undertake in doing so. Enterprise Risk Management - Understanding and Communicating Risk Appetite, research commissioned by the Committee of Sponsoring Organizations of the Treadway Commission (COSO), January 2012 , http://www.coso.org/documents/ERM-Understanding\%20\%20Communicating\%20Risk\%20Appetite-WEB FINAL r9.pdf
} 


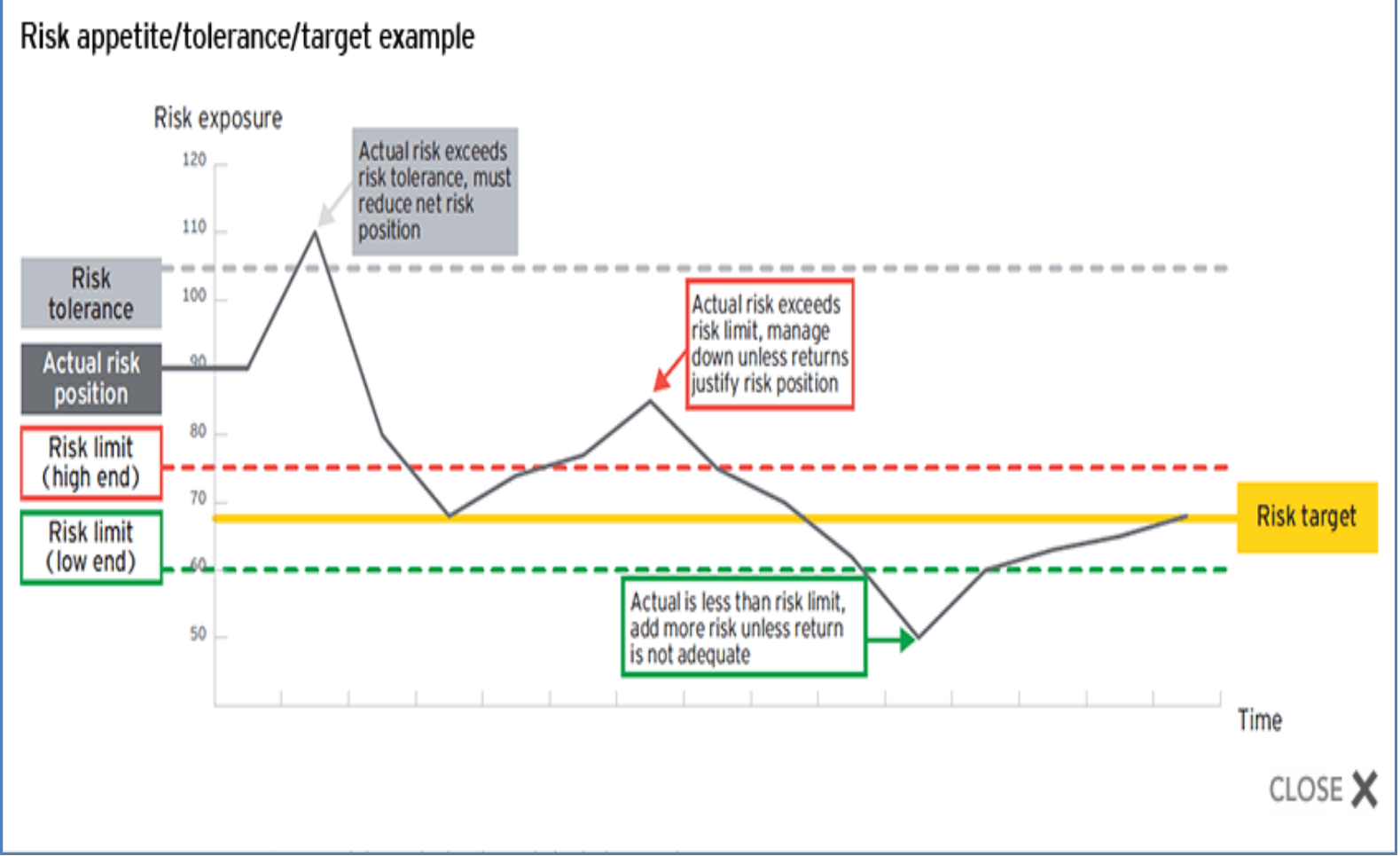

Falling within a creditor-firm's risk appetite is shown in the graph above as that point marked as "Risk target" and it is situated within that area bound by "Risk limit (high end)" and "Risk limit (low end)". Any point within this range (so-called risk appetite) is assured of credit approval.

To fall below the "Risk limit (low end)" as previously mentioned will not be appealing to any profit-seeking creditor-firm because returns in this area will not be enough to justify extending credit.

The area above the "Risk limit (high end)" is divided into two (2) parts drawn apart by a line marked as "Risk tolerance".

Credit scores falling below the "Risk tolerance" but above the "Risk limit (high end)" are justified propositions because returns still outweigh the risk taken by the creditor-firm though by a very slim margin. Meantime, credit scores located above the "Risk tolerance" are likely to be denied further consideration for the reason that returns are not justified relative to the risks taken.

\section{Striking a Balance between Risks and Profits}

When a proper balance between risk and profit is struck, it is at that point where the creditor-firm makes the decision to approve the line of credit sought by the debtor-firm. This is graphically shown below in Graph V.a as point (E) where the debtor-firm whose credit score is $\mathrm{S}_{\mathrm{C}} *$ is granted a line of credit bearing an interest rate of $\mathrm{I}_{\mathrm{R}} *$ by the creditor-firm. 

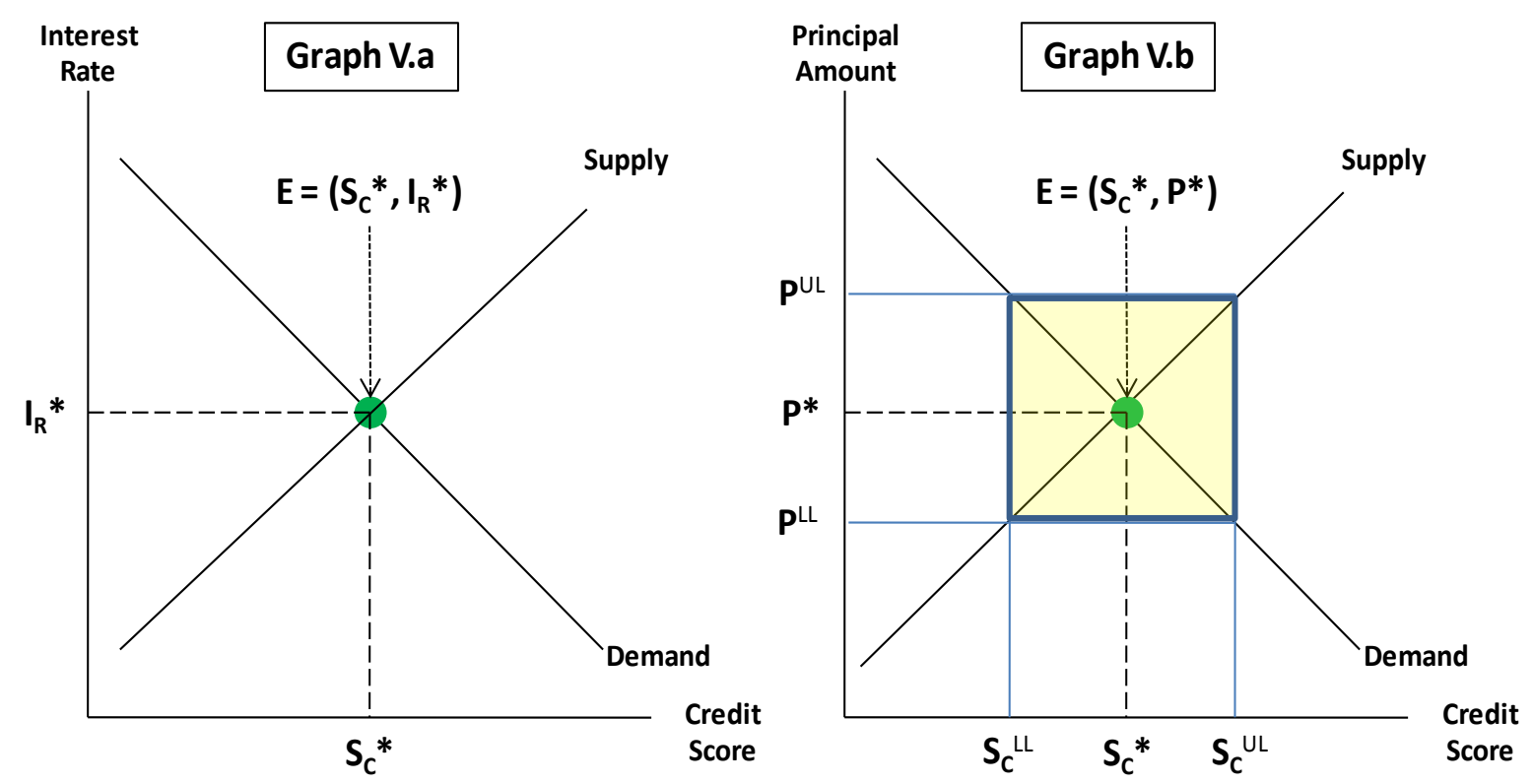

The creditor-firm's decision-making process may likewise be expressed mathematically as follows

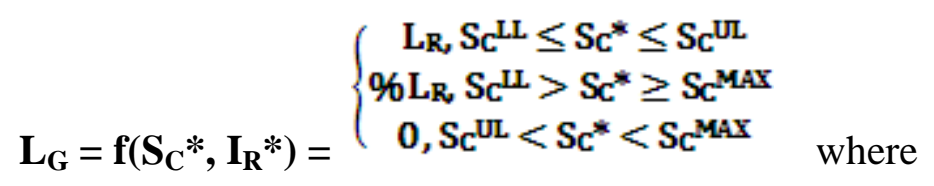

$\Rightarrow \mathbf{L}_{\mathbf{G}}$ refers to the loan amount granted by the creditor-firm and is a function of the debtor-firm's credit score $\left(\mathbf{S}_{\mathbf{C}}{ }^{*}\right)$ and interest rate on the loan $\left(\mathbf{I}_{\mathbf{R}}{ }^{*}\right)$,

$\Rightarrow \mathbf{L}_{\mathbf{R}}$ refers to the loan amount requested/applied for by the debtor-firm,

$\Rightarrow \boldsymbol{\%} \mathbf{L}_{\mathbf{R}}$ refers to the loan amount requested/applied for by the debtor-firm that is, at least equal to the minimum loan amount $\left(\mathrm{L}_{\mathrm{MIN}}\right)$ but less than

$\mathrm{L}_{\mathrm{R}}$ such that $\mathrm{L}_{\mathbf{M I N}} \leq \%_{\mathrm{L}_{\mathrm{R}}}{ }^{*}<\mathrm{L}_{\mathbf{R}} . \quad \mathrm{L}_{\mathrm{R}}$ is prompted when the debtor-firm's credit score $\left(\mathrm{S}_{\mathrm{C}}{ }^{*}\right)$ falls below the credit score-lower limit $\left(\mathrm{S}_{\mathrm{C}}{ }_{\mathrm{CL}}\right)$ but is greater than or equal to credit score-maximum tolerance $\left(\mathrm{S}_{\mathrm{C}}{ }^{\mathrm{MAX}}\right)$. $\% \mathrm{~L}_{\mathrm{R}}$ gets approved because of profit consideration $\left(\mathrm{I}_{\mathrm{R}}{ }^{*}\right)$,

$\Rightarrow \mathbf{S}_{\mathbf{C}}{ }^{\mathbf{L L}}$ refers to the credit score-lower limit,

$\Rightarrow \mathbf{S}_{\mathbf{C}}{ }^{\mathrm{UL}}$ refers to the credit score-upper limit, and

$\Rightarrow \mathbf{S}_{\mathbf{C}}{ }^{\mathbf{M A X}}$ refers to the credit score-maximum tolerance.

The equation above simply states that the creditor-firm will extend credit to the debtor-firm at $\mathrm{L}_{\mathrm{G}}=\mathrm{L}_{\mathrm{R}}$ provided the debtor-firm's credit score $\left(\mathrm{S}_{\mathrm{C}}{ }^{*}\right)$ falls within creditor-firm's risk appetite 


\section{Mll Macrothink}

International Journal of Accounting and Financial Reporting

bound by the credit score-lower limit $\left(\mathrm{S}_{\mathrm{C}}{ }^{\mathrm{LL}}\right)$ and credit score-upper limit $\left(\mathrm{S}_{\mathrm{C}}{ }^{\mathrm{UL}}\right)$.

On the other hand, the creditor-firm will deny credit to the debtor-firm (that is, $\mathrm{L}_{\mathrm{G}}=0$ ) should it happen that the debtor-firm's credit score falls anywhere outside the creditor-firm's risk appetite. This could either mean that the debtor-firm's credit score is less than the credit score-maximum tolerance (such that $\mathrm{Sc}^{\mathrm{MAN}}>\mathrm{Sc}^{*}$ ) or that the debtor-firm's credit score is greater than the credit score-upper limit (such that $\mathrm{Sc}^{*}>\mathrm{Sc}^{\mathrm{UI}}$ ).

Recall from our discussions in Section 6 (Risk Appetite) that creditor-firms vary from one another in terms of risk appetite. Some creditor-firms are risk-averse while other creditor-firms enjoy taking risks.

From Graph V.b, a creditor-firm's risk appetite is that area bound by credit score-lower limit $\left(\mathrm{S}_{\mathrm{C}}{ }^{\mathrm{LL}}\right)$ and credit score-upper limit $\left(\mathrm{S}_{\mathrm{C}}{ }^{\mathrm{UL}}\right)$. Note from the same graph that $\mathrm{S}_{\mathrm{C}}{ }^{\mathrm{UL}}$ represent that point where credit scores are high relative to $S_{C} *$ while $S_{C}{ }^{L L}$ pertain to that point where credit scores are low relative to $\mathrm{S}_{\mathrm{C}} *$ such that $\mathrm{S}_{\mathrm{C}}{ }^{\mathrm{UL}}>\mathrm{S}_{\mathrm{C}}{ }^{\mathrm{LL}}$.

Observe that at point $\mathrm{S}_{\mathrm{C}}{ }^{\mathrm{LL}}$, the debtor-firm's demand curve is greater than the creditor-firm's supply curve. That is at point $\mathrm{S}_{\mathrm{C}}{ }^{\mathrm{LL}}$, the creditor-firm is only willing to extend credit up to principal amount-lower limit $\left(\mathrm{P}^{\mathrm{LL}}\right)$ which is considerably lower to what the debtor-firm is asking for which is principal amount-upper limit $\left(\mathrm{P}^{\mathrm{UL}}\right)$. The creditor-firm is expected to behave this way since it would want to restrict its credit exposure relative to the debtor-firm whose credit score is below average at $\mathrm{S}_{\mathrm{C}}{ }^{\mathrm{LL}}$.

Examine now point $S_{C}{ }^{U L}$ where the creditor-firm's supply curve is greater than the debtor-firm's demand curve. At the point $\mathrm{S}_{\mathrm{C}}{ }^{\mathrm{UL}}$, the debtor-firm only asks for the principal amount-lower limit $\left(\mathrm{P}^{\mathrm{LL}}\right)$ but the creditor-firm is willing to grant credit up to the principal amount-upper limit $\left(\mathrm{P}^{\mathrm{UL}}\right)$. The creditor-firm is expected to behave this way since it would want to maximize its profit potential relative to the debtor-firm whose credit score is above average at $\mathrm{S}_{\mathrm{C}}{ }^{\mathrm{UL}}$. 


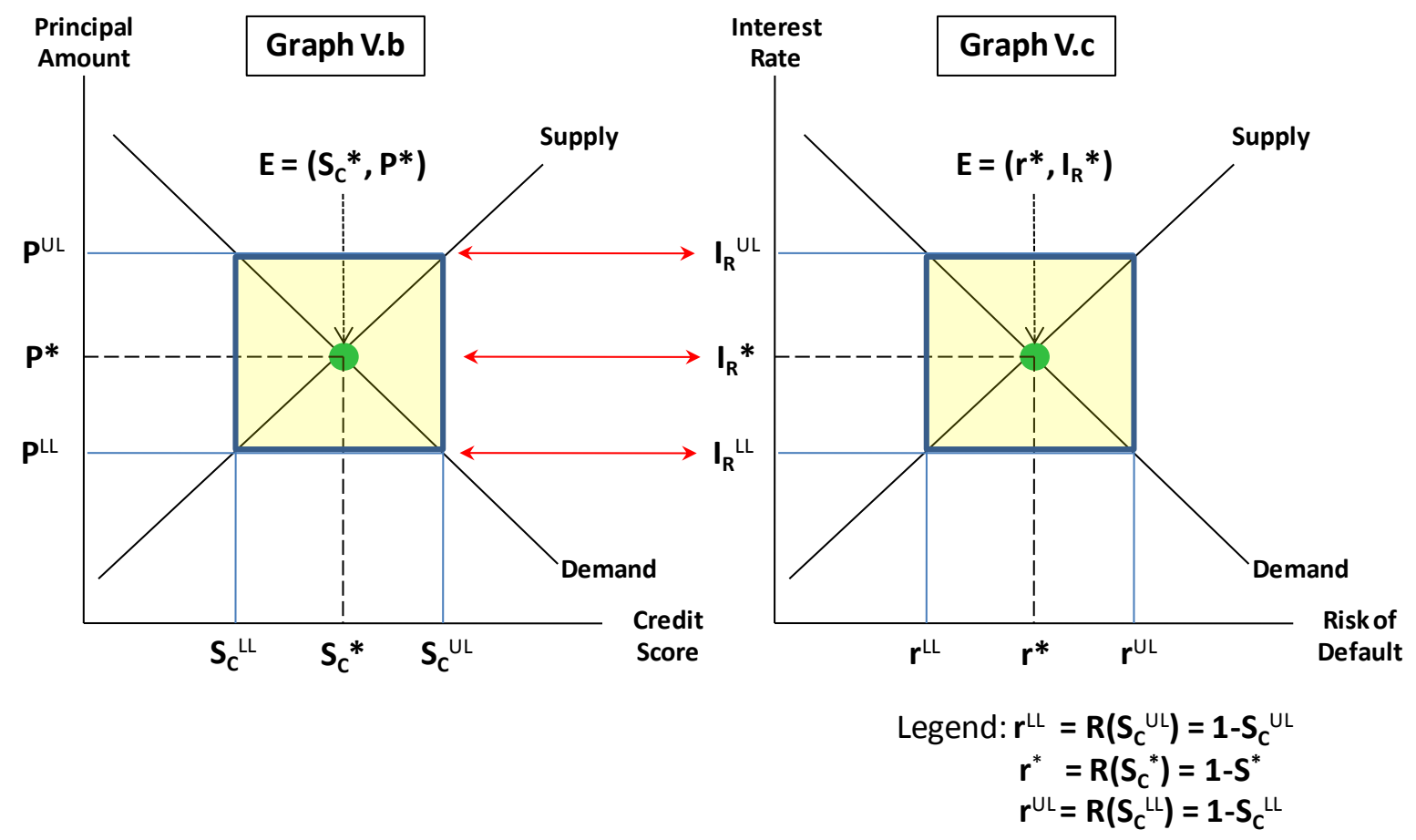

Graph V.c is a mirror image of Graph V.b except that the labels on the x-axis and y-axis have been changed to show instead the "Risk of Default" and the "Interest Rate", respectively whereas in Graph V.b the x-axis and y-axis were initially tagged as "Credit Score" and "Principal Amount", respectively.

As shown in the Legend under Graph V.c, risk of default (r) is visibly a function of the credit score $\left(S_{C}\right)$ except that it behaves in the opposite manner. The expression $r=R\left(S_{C}\right)=1-S_{C}$ captures the likelihood that the debtor-firm will incur default. From the same expression, we can also derive the statement which says "the higher the credit score, the lower the risk of default and vice-versa".

The following mathematical expressions (as shown in the Legend under Graph V.c) are derived in similar fashion as " $r$ " and also conforms to the same statement "the higher the credit score, the lower the risk of default and vice-versa".

$$
\begin{aligned}
& \Rightarrow \mathrm{r}^{\mathrm{LL}}=\mathrm{R}\left(\mathrm{S}_{\mathrm{C}}{ }^{\mathrm{UL}}\right)=1-\mathrm{S}_{\mathrm{C}}{ }^{\mathrm{UL}}, \\
& \Rightarrow \mathrm{r}^{*}=\mathrm{R}\left(\mathrm{S}_{\mathrm{C}}{ }^{*}\right)=1-\mathrm{S}_{\mathrm{C}}{ }^{*}, \text { and } \\
& \Rightarrow \mathrm{r}^{\mathrm{UL}}=\mathrm{R}\left(\mathrm{S}_{\mathrm{C}}{ }^{\mathrm{LL}}\right)=1-\mathrm{S}_{\mathrm{C}}{ }^{\mathrm{LL}},
\end{aligned}
$$

Therefore, it can be said that the creditor-firm's decision-making process may be rewritten in terms of risk of default (r) and mathematically expressed as follows

$\mathbf{L}_{\mathbf{G}}=\mathbf{f}\left(\mathbf{r}^{*}, \mathbf{I}_{\mathbf{R}}^{*}\right)=\left\{\begin{array}{c}\mathbf{L}_{\mathrm{R}} \mathbf{r}^{\mathrm{IL}} \leq \mathbf{r}^{*} \leq \mathbf{r}^{\mathrm{UL}} \\ \% \mathrm{~L}_{\mathrm{R}} \mathbf{r}^{\mathrm{UL}}<\mathbf{r}^{*} \leq \mathbf{r}^{\mathrm{MAX}} \\ \mathbf{0 ,} \mathbf{r}^{\mathrm{LL}}>\mathbf{r}^{*}>\mathbf{r}^{\mathrm{MAX}} \quad \text { where }\end{array}\right.$ 
$\Rightarrow \mathbf{L}_{\mathbf{G}}$ refers to the loan amount granted by the creditor-firm and is a function of the debtor-firm's risk of default rating $\left(\mathbf{r}^{*}\right)$ and interest rate on the loan $\left(\mathbf{I}_{\mathbf{R}}{ }^{*}\right)$,

$\Rightarrow \mathbf{L}_{\mathbf{R}}$ refers to the loan amount requested/applied for by the debtor-firm,

$\Rightarrow \% \mathbf{L}_{\mathbf{R}}$ refers to the loan amount requested/applied for by the debtor-firm that is, at least equal to the minimum loan amount $\left(\mathrm{L}_{\mathrm{MIN}}\right)$ but less than $\mathrm{L}_{\mathrm{R}}$ such that $\mathbf{L}_{\mathbf{M N}} \leq \% \mathrm{~L}_{\mathrm{R}}{ }^{*}<\mathrm{L}_{\mathbf{R}} . \quad \mathrm{L}_{\mathrm{R}}$ is prompted when the debtor-firm's risk of default rating $\left(\mathrm{r}^{*}\right)$ falls above risk of default rating-upper limit $\left(\mathrm{r}^{\mathrm{UL}}\right)$ but is less than or equal to risk of default rating-maximum tolerance $\left(\mathrm{r}^{\mathrm{MAX}}\right)$. $\% \mathrm{~L}_{\mathrm{R}}$ gets approved because of profit considerations $\left(\mathrm{I}_{\mathrm{R}}{ }^{*}\right)$,

$\Rightarrow \mathbf{r}^{\mathbf{L L}}$ refers to the risk of default rating-lower limit,

$\Rightarrow \mathbf{r}^{\mathrm{UL}}$ refers to the risk of default rating-upper limit, and

$\Rightarrow \mathbf{r}^{\mathrm{MAX}}$ refers to the risk of default rating-maximum tolerance

The equation above simply states that the creditor-firm will extend credit to the debtor-firm at $\mathrm{L}_{\mathrm{G}}=\mathrm{L}_{\mathrm{R}}$ provided the debtor-firm's risk of default rating $\left(\mathrm{r}^{*}\right)$ falls within creditor-firm's risk appetite bound by the risk of default rating-lower limit $\left(\mathrm{r}^{\mathrm{LL}}\right)$ and risk of default rating-upper $\operatorname{limit}\left(\mathrm{r}^{\mathrm{UL}}\right)$.

On the other hand, the creditor-firm will deny credit to the debtor-firm (that is, $\mathrm{L}_{\mathrm{G}}=0$ ) should it happen that the debtor-firm's risk of default rating $\left(r^{*}\right)$ falls anywhere outside the creditor-firm's risk appetite. This could either mean that the debtor-firm's risk of default rating $\left(\mathrm{r}^{*}\right)$ is less than the risk of default rating-lower limit (such that $\mathrm{r}^{\mathrm{LL}}>\mathrm{r}^{*}$ ) or that the debtor-firm's risk of default rating $\left(\mathrm{r}^{*}\right)$ exceeds the risk of default rating-maximum tolerance (such that $\mathrm{r}^{*}>\mathrm{r}^{\mathrm{MAx}}$ ).

Observe that at point $r^{\mathrm{LL}}$ from Graph V.c, the debtor-firm's demand curve is greater than the creditor-firm's supply curve. That is at point $r^{\mathrm{LL}}$, the creditor-firm is only willing to extend credit up to principal amount-lower limit $\left(\mathrm{P}^{\mathrm{LL}}\right)$ which is considerably lower to what the debtor-firm is asking for which is principal amount-upper limit $\left(\mathrm{P}^{\mathrm{UL}}\right)$. The creditor-firm is expected to behave this way because it can only charge a low interest rate $\left(\mathrm{I}_{R}{ }^{\mathrm{LL}}\right)$ since the risk of default rating of the debtor-firm is also low $\left(\mathrm{r}^{\mathrm{LL}}\right)$.

Examine now point $\mathrm{r}^{\mathrm{UL}}$ where the creditor-firm's supply curve is greater than the debtor-firm's demand curve. At the point $\mathrm{r}^{\mathrm{UL}}$, the debtor-firm only asks for the principal amount-lower limit $\left(\mathrm{P}^{\mathrm{LL}}\right)$ but the creditor-firm is willing to grant credit up to the principal amount-upper limit $\left(\mathrm{P}^{\mathrm{UL}}\right)$. The creditor-firm is encouraged to behave this way given that it 
wants to maximize its profit potential by way of increasing the principal amount (from $\mathrm{P}^{\mathrm{LL}}$ up to $\mathrm{P}^{\mathrm{UL}}$ ) and charging higher interest rate (from $\mathrm{I}_{\mathrm{R}}{ }^{\mathrm{LL}}$ to $\mathrm{I}_{\mathrm{R}}{ }^{\mathrm{UL}}$ ).
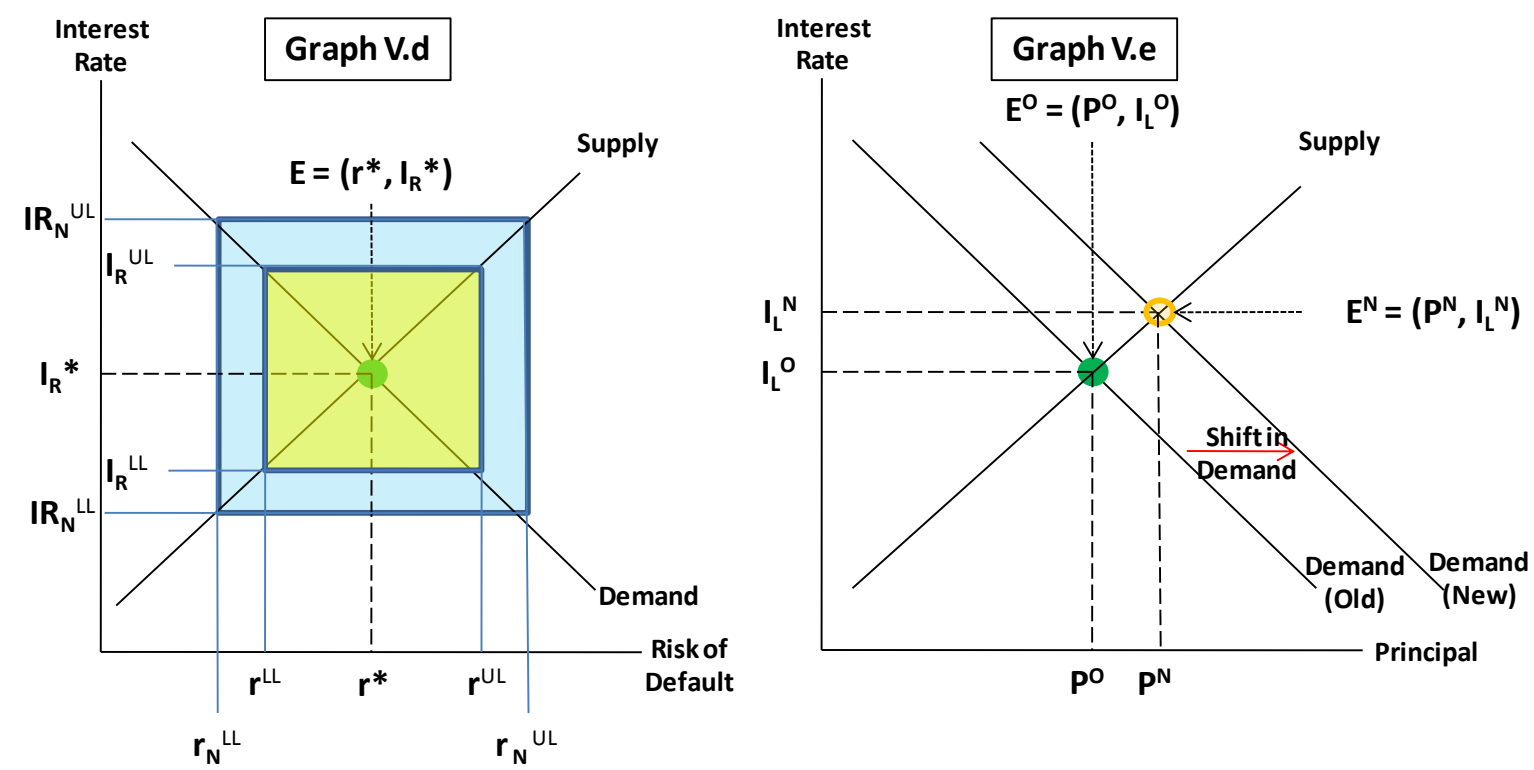

So how does a creditor-firm increase its revenues $\left(\mathrm{I}_{\mathrm{L}}\right)$ over a given period of time? The answer is apparent from Graph V.d which suggests that the creditor-firm will have to relax a bit its risk threshold. This is tantamount to expanding the creditor-firm's risk appetite such that it now caters to a bigger clientele.

From the previous graphs (V.b and V.c), the yellow-shaded box represented the creditor-firm's initial level of profits bound along the $\mathrm{x}$-axis at points, $\mathrm{r}^{\mathrm{LL}}$ and $\mathrm{r}^{\mathrm{UL}}$ and along the $y$-axis at points $\mathrm{I}_{\mathrm{R}}{ }^{\mathrm{LL}}$ and $\mathrm{I}_{\mathrm{R}}^{\mathrm{UL}}$.

When its risk appetite was relaxed a bit from $r^{\mathrm{LL}}$ to $\mathrm{r}_{\mathrm{N}}^{\mathrm{LL}}$ and from $\mathrm{r}^{\mathrm{UL}}$ to $\mathrm{r}_{\mathrm{N}}^{\mathrm{UL}}$, the creditor-firm benefitted in two (2) ways.

- Whereas it used to charge only $\mathrm{I}_{\mathrm{R}}{ }^{\mathrm{UL}}$ to debtor-firms bearing risk of default rating, $\mathrm{r}^{\mathrm{UL}}$, the creditor-firm may now take on more loans bearing higher risk of default rating, $\mathrm{r}_{\mathrm{N}}{ }^{\mathrm{UL}}$ and collect a greater amount of interest, $\mathrm{IR}_{\mathrm{N}}{ }^{\mathrm{UL}}$.

- With regard to debtor-firm's bearing low risk of default rating, $r^{\mathrm{LL}}$, the creditor-firm can only charge low/competitive interest rate, $\mathrm{I}_{\mathrm{R}}{ }^{\mathrm{LL}}$ since debt collection is almost assured. Although it cannot charge any higher than $\mathrm{I}_{R}{ }^{\mathrm{LL}}$, the creditor-firm benefits from the foregoing strategy through volume expansion. In other words, the creditor-firm may now grant credit to debtor-firms bearing far superior risk of default rating $\left(\mathrm{r}_{N}{ }^{\mathrm{LL}}\right)$ while realizing a reasonable return $\left(\mathrm{IR}_{\mathrm{N}}^{\mathrm{LL}}\right)$.

In Graph V.d, the improved level of profit is represented by the blue-shaded box bound along the $\mathrm{x}$-axis at points, $\mathrm{r}_{\mathrm{N}}{ }^{\mathrm{LL}}$ and $\mathrm{r}_{\mathrm{N}}^{\mathrm{UL}}$ and along the $\mathrm{y}$-axis at points $\mathrm{IR}_{\mathrm{N}}{ }^{\mathrm{LL}}$ and $\mathrm{IR}_{\mathrm{N}}{ }^{\mathrm{UL}}$.

By simply looking at Graph V.d, it is apparent that the blue-shaded box is far bigger than the 
yellow-shaded box which suggests that profit is higher when the risk appetite of the creditor-firm was relaxed a bit.

It does not mean however that creditor-firms must follow the strategy illustrated above. Risk-averse creditor-firms are likely to expand their risk appetite so that they can cater to more debtor-firms bearing lower risk of default ratings. Risk-averse creditor-firms do this to benefit from volume expansion. On the other hand, risk-taking creditor-firms tend to adjust their risk appetite to the point of taking in more risk. Insofar as risk-taking creditor-firms are concerned, the opportunity to earn higher-than-normal profits provides sufficient justification for their actions.

When a creditor-firm widens its risk appetite so much so that it caters to a bigger clientele, it has the effect of increasing the principal amount made available to debtor-firms. Said increase in principal amount is shown in Graph V.e as a shift along the creditor-firm's supply curve. In reaction to this, more debtor-firms start lining up to submit their credit applications. The heightened demand for credit is shown in Graph V.e as a shift of the entire debtor-firm's demand curve. The interaction of the creditor-firm's supply curve and debtor-firm's demand curve resulted in a new equilibrium point $\left(\mathrm{E}^{\mathrm{N}}\right)$. Note that the old equilibrium point was at point, $\mathrm{E}^{\mathrm{O}}$.

From Graph V.e, we are able to confirm that at point $\left(\mathrm{E}^{\mathrm{N}}\right)$ creditor-firms are made better off by the decision to expand their risk appetite since $\mathrm{I}_{\mathrm{L}}{ }^{\mathrm{N}}>\mathrm{I}_{\mathrm{L}}{ }^{\mathrm{O}}$. The same applies for debtor-firms as well since $\mathrm{P}^{\mathrm{N}}>\mathrm{P}^{\mathrm{O}}$. This could either mean that a greater number of debtor-firms were granted credit or additional lines of credit were provided to existing debtor-firms.

Expressed in terms of an equation, the profit-maximization problem of the creditor-firm $\left(\boldsymbol{\pi}_{\mathbf{C}}\right)$ will be that

$\operatorname{Max} \pi_{C}=\mathbf{I}\left(\mathbf{I}_{R}, \mathbf{L}_{G}\right)-\mathbf{c}\left(\mathbf{E}_{\mathbf{O}}, \mathbf{I}_{\mathbf{B}}\right)$ where

$\Rightarrow \mathbf{I}\left(\mathbf{I}_{\mathbf{R}}, \mathbf{L}_{\mathbf{G}}\right)$ is a revenue function and it refers to the interest income earned on loans granted to debtor-firms,

$\Rightarrow \mathbf{I}_{\mathbf{R}}$ refers to the interest rate on loans,

$\Rightarrow \mathbf{L}_{\mathbf{G}}$ refers to the loan amount granted by the creditor-firm,

$\Rightarrow \mathbf{c}\left(\mathbf{E}_{\mathbf{O}}, \mathbf{I}_{\mathbf{B}}\right)$ is a cost function and it collectively refers to operating costs of the creditor-firm and interest expenses incurred on borrowed capital,

$\Rightarrow \mathbf{E}_{\mathbf{O}}$ refers to the operating expenses of the creditor-firm excluding provisions for bad debts and interest expenses incurred from borrowed capital, and

$\Rightarrow \mathbf{I}_{\mathbf{B}}$ refers to interest expenses incurred on borrowed capital from stakeholders

Similarly, debtor-firms' profit-maximization problem $\left(\boldsymbol{\pi}_{\mathbf{D}}\right)$ can also be expressed 


\section{1) Macrothink}

mathematically as follows

$\operatorname{Max} \pi_{D}=\mathbf{R}\left(\mathbf{G S}, \mathbf{P}_{G S}\right)-\mathbf{c}\left(\mathbf{C}_{G S}, \mathbf{E}_{\mathbf{O}}, \mathbf{I}_{\mathbf{B}}\right)$ where

$\Rightarrow \mathbf{R}\left(\mathbf{G S}, \mathbf{P}_{\mathbf{G S}}\right)$ is a revenue function and it refers to revenues generated from the sale of goods and services,

$\Rightarrow$ GS refers to the inventory of goods and services available for sale,

$\Rightarrow \mathbf{P}_{\mathbf{G S}}$ refers to the price of each and every inventory of goods and services available for sale,

$\Rightarrow \mathbf{c}\left(\mathbf{C}_{\mathbf{G S}}, \mathbf{E}_{\mathbf{O}}, \mathbf{I}_{\mathbf{B}}\right)$ is a cost function and it collectively refers to the cost of goods and services sold, operating expenses of the debtor-firm, and interest expenses incurred on borrowed capital,

$\Rightarrow \mathbf{C}_{\mathbf{G S}}$ refers to the cost of goods and services sold,

$\Rightarrow \mathbf{E}_{\mathbf{O}}$ refers to operating expenses of the debtor-firm excluding provisions for bad debts and interest expenses incurred from borrowed capital, and

$\Rightarrow \mathbf{I}_{\mathbf{B}}$ refers to interest expenses incurred on borrowed capital from the creditor-firm.

\section{Main Results}

\subsection{The Problem of Information Asymmetry}

Refer now to the following diagram which illustrates the problem of asymmetric information ${ }^{15}$ faced by creditor-firms relative to debtor-firms.

15 This is a situation where there is imperfect knowledge. In particular, it occurs where one party has different information to another. A good example is when selling a car the owner is likely to have full knowledge about its service history and likelihood to break down. The potential buyer, by contrast, will be in the dark and he may not be able to trust the car salesman. http://www.economicshelp.org/dictionary/a/asymmetric-information.html 


\section{Problem of Information Asymmetry}

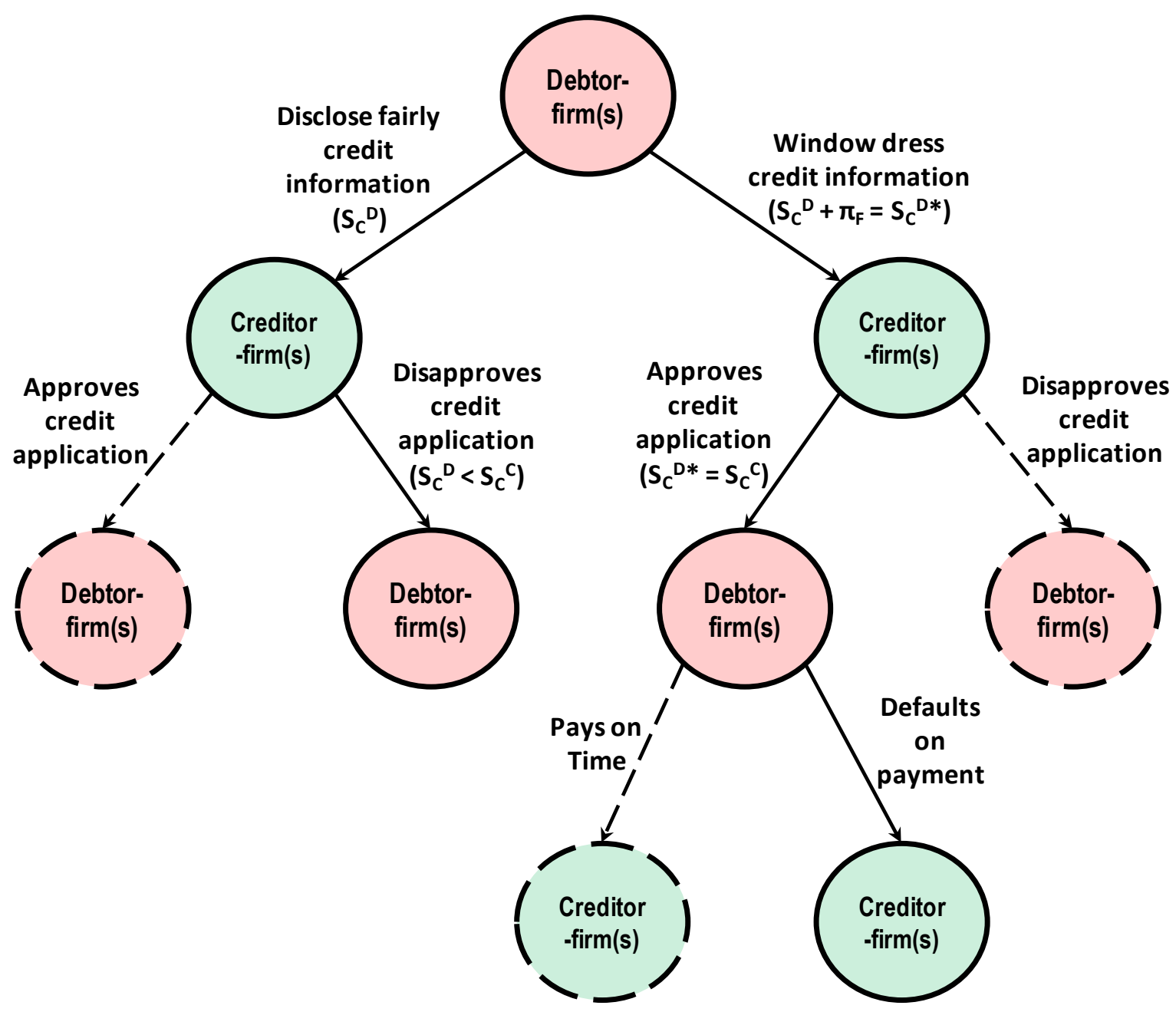

The diagram reveals that the debtor-firm may either disclose fairly or window dress its credit information when applying for credit.

If the debtor-firm opts to disclose fairly its credit information, the creditor-firm is likely to disapprove its credit application should it be the case that $\mathrm{S}_{\mathrm{C}}{ }^{\mathrm{D}}<\mathrm{S}_{\mathrm{C}}{ }^{\mathrm{C}}$. This is because the credit score of the debtor-firm $\left(\mathrm{S}_{\mathrm{C}}{ }^{\mathrm{D}}\right)$ would have failed to meet the creditor-firm's criteria for credit approval $\left(\mathrm{S}_{\mathrm{C}}{ }^{\mathrm{C}}\right)$. We assume at least, in this part of the research that $\mathrm{S}_{\mathrm{C}}{ }^{\mathrm{C}}$ refers to the creditor-firm's risk appetite bound by credit score-lower limit $\left(\mathrm{S}_{\mathrm{C}}{ }^{\mathrm{LL}}\right)$ and credit score-upper limit $\left(\mathrm{S}_{\mathrm{C}}{ }^{\mathrm{UL}}\right)$ for simplicity.

On the other hand, the outcome would have different if the debtor-firm chose to window dress $^{16}$ its credit information. For example, the debtor-firm may include a fictitious source

\footnotetext{
${ }^{16}$ In accounting terms, window dressing refers to an assortment of alterations a bookkeeper might make to a financial statement, whether legal or illegal, so that the statement appears stronger than it is. Omitting expenses, recording sales before they occur, or delaying write-offs are possible window dressing activities in this context. A firm might engage in the accounting version of window dressing to meet liquidity requirements on financial disclosure forms. http://www.investorglossary.com/window-dressing.htm
} 
of income in its credit information to improve its liquidity position. The same objective is achieved if and when the debtor-firm chooses to withhold information about its operating expenses. Regardless of the approach taken, what once was a lowly credit score of only $\mathrm{S}_{\mathrm{C}}{ }^{\mathrm{D}}$ has been improved to $S_{C}{ }^{D} *$. Unless the creditor-firm does its due diligence properly, the debtor-firm is likely to be granted credit since $\mathrm{S}_{\mathrm{C}}{ }^{\mathrm{D}} * \mathrm{~S}_{\mathrm{C}}{ }^{\mathrm{C}}$. That is, the fraudulently derived credit score of the debtor-firm $\left(\mathrm{S}_{\mathrm{C}}{ }^{\mathrm{D}} *\right)$ falls within the risk appetite of the creditor-firm $\left(\mathrm{S}_{\mathrm{C}}{ }^{\mathrm{C}}\right)$.

Whenever an instalment falls due and the debtor-firm fails to make payment on time, it is usually the case that a creditor-firm charges a penalty for late payment $\left(\mathrm{P}_{\mathrm{LP}}\right)$. The assessment of late payment penalty $\left(\mathrm{P}_{\mathrm{LP}}\right)$ is meant to encourage debtor-firms to make prompt payments as these represent additional but unnecessary costs for servicing the loan. Like interest rates on loans, late payment penalties are typically expressed as percentages ( $\left.\mathrm{I}_{\mathrm{PLP}}\right)$ and are determined on the basis of the amount in arrears (A) and the time that had lapsed since the debtor-firm made payment to update its account $\left(\mathrm{T}_{\mathrm{UA}}\right)$. In mathematical terms, late payment penalties may be expressed as $\mathrm{P}_{\mathrm{LP}}=\mathrm{f}\left(\mathrm{A}, \mathrm{T}_{\mathrm{UA}}\right)$.

Like debtor-firms, operations of creditor-firms get hit as well whenever there are delays in the payment of instalments due. These hits come in the form of provisions for bad debts ${ }^{17}$ $\left(\mathrm{BD}_{\mathrm{E}}\right)$. Bad debts (sometimes called doubtful accounts) are reported in the accounting records of creditor-firms as part of their operating expenses and have the effect of reducing the book value of receivables to net realizable value ${ }^{18}$.

There exist three (3) methods in estimating the allowance for bad debts, namely:

1. Aging the accounts receivable (statement of financial position) approach ${ }^{19}$

2. Percent-of-receivables (statement of financial position) approach

3. Percentage-of-sales (income statement) approach

Of the methods, aging the accounts receivable approach is most commonly used. The aging of accounts receivable involves an analysis of the accounts where they are classified into not due or past due. Past due accounts are further classified in terms of the length of the period they are past due. The common classifications are:

- Not due

- 1 to 30 days past due

\footnotetext{
17 Definition of 'Allowance for Bad Debt' - A valuation account used to estimate the portion of a bank's loan portfolio that will ultimately be uncollectible. When a loan goes bad, the asset is removed from the books and the allowance for bad debt is charged for the book value of the loan. These are also known as "loan-loss reserve". http://www.investopedia.com/terms/a/allowance-for-bad-debt.asp

${ }^{18}$ Net realizable value is defined as the amount of cash expected to be collected or the estimated recoverable amount. Refer to the section "Accounts Receivable" on page 271, FINANCIAL ACCOUNTING Volume One 2012 Edition, Conrado T. Valix, Jose F. Peralta and Christian Aris M. Valix

19 Estimating doubtful accounts - aging, percentage of accounts receivable and percentage of sales, Chapter 6 Accounts Receivable, page 279-280, FINANCIAL ACCOUNTING Volume One 2012 Edition, Conrado T. Valix, Jose F. Peralta and Christian Aris M. Valix
} 
- 31 to 60 days past due 2013, Vol. 3, No. 1

- 61 to 90 days past due

- 91 to 120 days past due

- 121 to 180 days past due

- 181 to 365 days past due

- More than 1 year past due

- Bankrupt or under litigation

The allowance is then determined by multiplying the total of each classification (AR) by the rate or percent of loss experienced ${ }^{20}$ by the entity for each category $\left(E_{R}\right)$.

The major argument for the use of this method is the more accurate and scientific computation of the Allowance for Bad Debts, and consequently, the accounts receivable are fairly presented in the statement of financial position at net realizable value.

\section{Illustration $\mathbf{1}^{21}$}

The following data are summarized in aging the accounts receivable of Sabrina Mae Company as of December 31, 2011:

(a)

Accounts

Not due

1-30 days past due

31-60 days past due

61-90 days past due

91-180 days past due

181-365 days past due

More than one year

Total (b) (a x b)

Experience Required

rate allowance

$1 \% \quad \mathrm{P} \quad 5,000$

$3 \% \quad 9,000$

$5 \% \quad 10,000$

$\begin{array}{rcr}100,000 & 8 \% & 8,000 \\ 50,000 & 15 \% & 7,500\end{array}$

$30,000 \quad 35 \% \quad 10,500$

$20,000 \quad 50 \%$

\begin{tabular}{ll}
$\mathbf{P \quad 1 , 2 0 0 , 0 0 0}$ & $\underline{\mathrm{P} \quad 60,000}$ \\
\hline
\end{tabular}

The amount computed by aging of accounts receivable represents the required Allowance for Bad Debts at the end of the period.

In mathematical terms, provisions for bad debts $\left(\mathrm{BD}_{\mathrm{E}}\right)$ may be expressed as $\mathrm{BD}_{\mathrm{E}}=\mathrm{f}\left(\mathrm{E}_{\mathrm{R}}, \mathrm{AR}\right)$.

As a result of payment defaults, the profit-maximization problems of the debtor-firm and

\footnotetext{
${ }^{20}$ Experience rating is a method used by insurers to determine pricing of premiums for different groups or individuals based on the group or individual's history of claims. The experience rating approach uses an individual's or group's historic data as a proxy for future risk, and insurers adjust and set insurance premiums and plans accordingly. http://en.wikipedia.org/wiki/Experience_rating

${ }^{21}$ Equivalence of the 3 Methods of Estimating Bad Debts, Damito D. Magpantay, International Journal of Science and Research (IJSR), India Online ISSN:2319-7064
} 
creditor-firm must therefore be revised to include the additional but unnecessary costs of servicing the loan such that:

For the creditor-firm,

$$
\begin{aligned}
\operatorname{Max} \pi_{\mathbf{C}}=\mathbf{I}\left(\mathbf{I}_{\mathbf{R}}, \mathbf{L}_{\mathbf{G}}\right) & +\mathbf{R}\left(\mathbf{P}_{\mathbf{L P}}\right)-\mathbf{c}\left(\mathbf{E}_{\mathbf{O}}, \mathbf{I}_{\mathbf{B}}, \mathbf{B D}_{\mathbf{E}}\right) \text { where } \\
& \Rightarrow \mathbf{R}\left(\mathbf{P}_{\mathbf{L P}}\right) \text { represent revenues from late payment penalties, and } \\
& \Rightarrow \mathbf{B} \mathbf{D}_{\mathbf{E}} \text { represent provisions for bad debts }
\end{aligned}
$$

For the debtor-firm,

$$
\begin{aligned}
\operatorname{Max} \pi_{\mathrm{D}}=\mathbf{R}\left(\mathrm{GS}, \mathbf{P}_{\mathrm{GS}}\right)-\mathbf{c}\left(\mathbf{C}_{\mathbf{G S}}, \mathbf{E}_{\mathbf{O}}, \mathbf{I}_{\mathbf{B}}, \mathbf{P}_{\mathrm{LP}}\right) \text { where } \\
\quad \Rightarrow \mathbf{P}_{\mathrm{LP}} \text { represent late payment penalties }
\end{aligned}
$$

If left unchecked, payment defaults will have the effect of reducing the profit potential and net asset value $\mathrm{e}^{22}$ of creditor-firms - issues of great concern to owners/stockholders of the creditor-firm.

The same implications apply to debtor-firms except that they may opt to not immediately recognize late payment penalties in their financial statements. This is typically the case of debtor-firms with outstanding requests for waiver of late payment penalty which have yet to be acted upon by the creditor-firms. Until such time that the late payment penalty is enforced by the creditor-firm, the only time owners/stockholders of the debtor-firm will be able to comprehend or sense that their company is in financial distress is when they look at their liquidity ratios ${ }^{23}$. By then, it may already be too late to apply corrective measures and make a quick turnaround ${ }^{24}$.

Payment defaults also have the effect of forcing risk-taking creditor-firms to not grow their loan portfolio in the near term. This means that risk-taking creditor-firms will react to payment defaults by maintaining current levels of spending - that is, granting enough new loans to offset maturing loans. To compensate for the lost income brought about by not expanding one's loan portfolio while taking account of the heightened risk of default, the creditor-firm may likely to be compelled to charge higher interest rates. Please refer to Graph V.f.

\footnotetext{
${ }^{22}$ Net Asset Value (NAV) - In stocks and businesses, an expression of the underlying value of the company. That is, it is a statement of the value of the company's assets minus the value of its liabilities. One way of thinking about the net asset value is that it is the underlying value of a company, not the value dictated by the supply and demand of shares or its market capitalization. It is also called the book value. http://financial-dictionary.thefreedictionary.com/Net+Asset+Value

${ }^{23}$ Liquidity Ratios - A class of financial metrics that is used to determine a company's ability to pay off its short-terms debts obligations. Generally, the higher the value of the ratio, the larger the margin of safety that the company possesses to cover short-term debts. http://www.investopedia.com/terms/l/liquidityratios.asp

24 Turnaround - The financial recovery of a company that has been performing poorly for an extended time. In order to effect a turnaround, a company must acknowledge and identify its problems, consider changes in management and develop and implement a problem-solving strategy. In some cases, the best strategy may be to cut losses by liquidating the company rather than trying to turn it around.

http://www.investopedia.com/terms/t/turnaround.asp
} 


\section{Macrothink}

International Journal of Accounting and Financial Reporting

ISSN 2162-3082

2013, Vol. 3, No. 1

Meanwhile, risk-averse creditor-firms may even go a bit further in reacting to payment defaults. By their very nature, risk-averse creditor-firms may decide to narrow further their risk appetite which would have the effect of scaling down their lending operations.

As the volume of new loans shrink alongside maturing debts, the risk-averse creditor-firm will soon find itself having to settle with and realize profit from a considerably smaller loan portfolio than what it was accustomed to in the past.

While its profit potential may have indeed been diminished, the risk-averse creditor-firm makes up for the lost income by being able to collect instalment payments on time. In other words, the risk-averse creditor-firm will have less to worry about since it has narrowly focused its attention to a more manageable loan portfolio it knows is less likely to incur payment default. Kindly refer to Graph V.g.
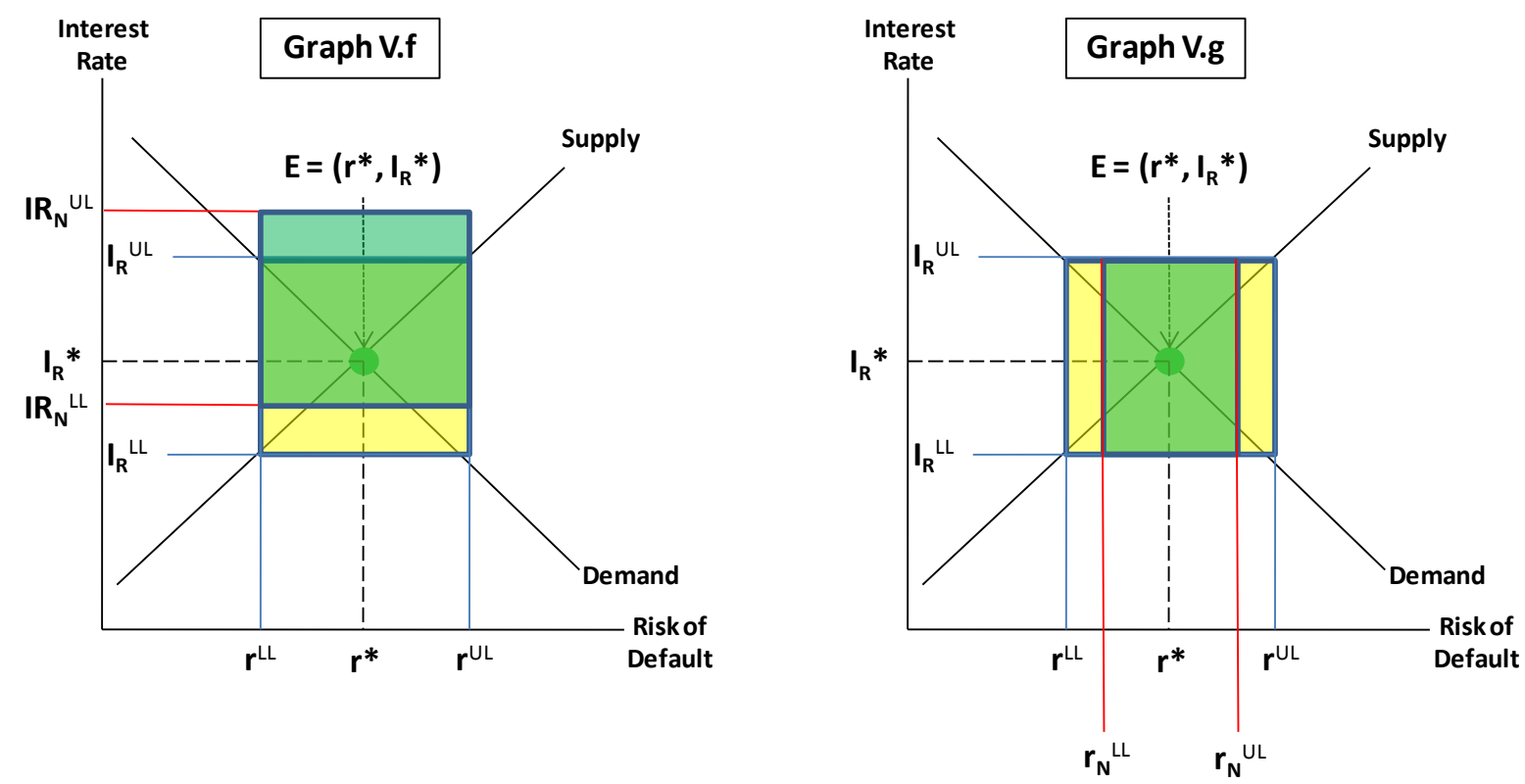

There is however another benefit to the risk-averse creditor-firm because it chose to further narrow its risk appetite as its strategy to counteract the effect of heightened payment default.

Note that from Graph V.h, the risk-averse creditor-firm maintained interest rates on loans whereas the risk-taking creditor-firm in Graph V.f increased interest rates on loans as a way to compensate for the higher incidence of default. Because it could afford to maintain its current pricing on loans, the risk-averse creditor-firm has now improved its competitive footing in the market. As more debtor-firms line up to submit their credit applications, the risk-averse creditor-firm can afford to become more discriminating with its choice of which debtor-firm to extend credit to. 


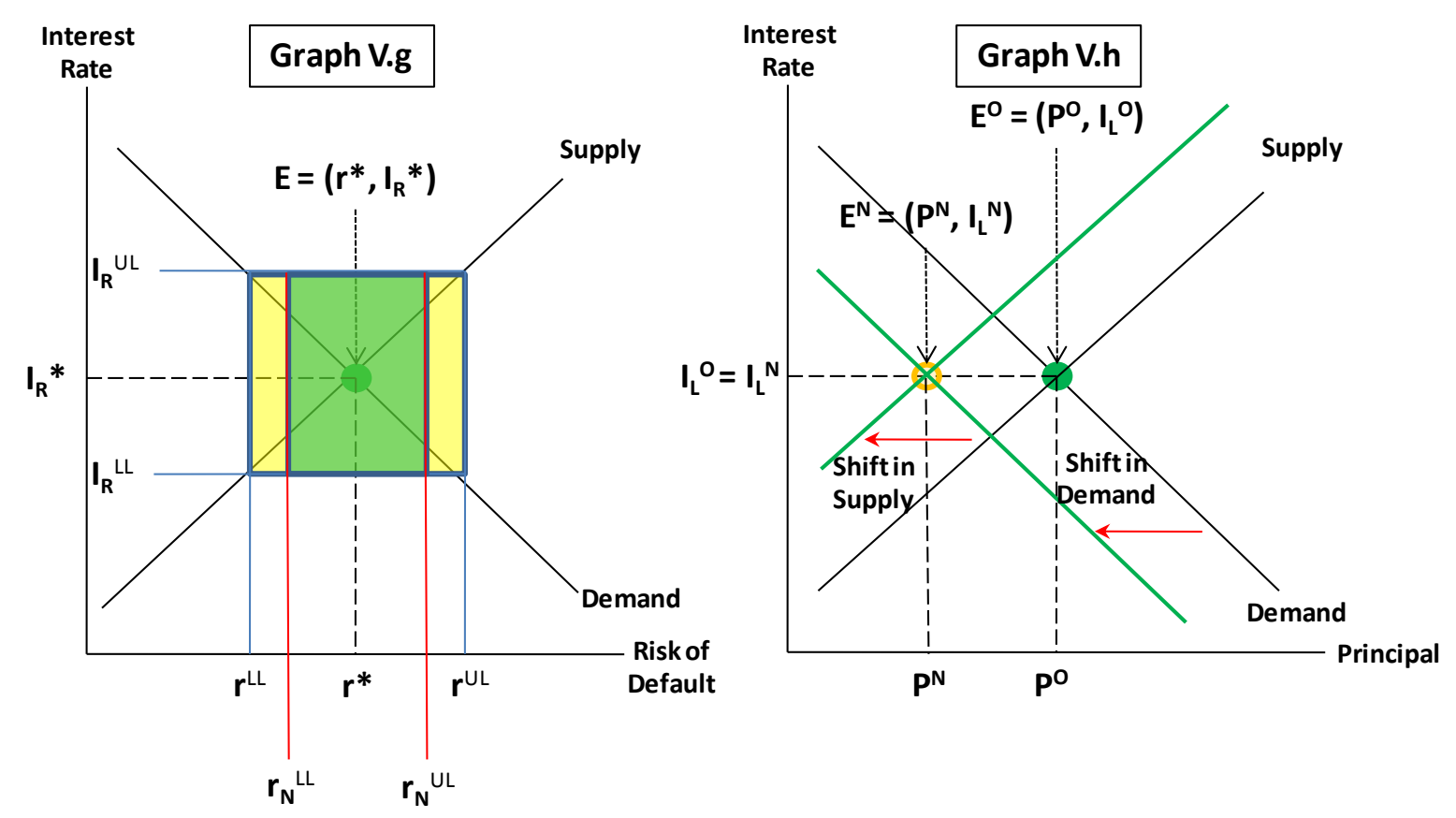

\subsection{Proposed Solution to Information Asymmetry}

The objective of this research is to provide a solution to the problem of information asymmetry encountered by creditor-firms arising from manipulative and deceptive practices employed by debtor-firms meant to incite credit approval.

In developing the solution to the problem of asymmetric information, this researcher took calculated steps to ensure that the behaviour of debtor-firms and creditor-firms are sufficiently explained and backed up by relevant microeconomic theories.

It should be noted from this point on that the problem of information asymmetry described in this research is not likely to be any different in other parts of the world. This is because what motivates scheming debtor-firms from continuously seeking credit through fraudulent means can be explained by the principle of more is better ${ }^{25}$.

Having established this fact, it should therefore be expected that the proposed solution to the problem of asymmetric information must likewise be of general application.

This researcher proposes to resolve the problem of information asymmetry through (1) the adoption of a new method to estimate allowance for bad debts - one which make use credit ratings - and (2) the formulation and implementation of accounting policies requiring firms to disclose their credit scores in their audited financial statements.

Presently, techniques used to estimate allowance for bad debts rely on experience rates which are based on the creditor-firm's historical account of receivables that become past due.

\footnotetext{
25 The More-Is-Better Principle. When one consumption bundle contains more of every good than a second bundle, a consumer prefers the first bundle to the second.

http://highered.mcgraw-hill.com/sites/d1/free/007290027x/449880/Sample Chapter.pdf
} 


\section{MInstitute Macrothink $_{\text {Int }}$}

International Journal of Accounting and Financial Reporting ISSN 2162-3082

While fairly easy to use, none of the abovementioned methods used to estimate allowance for bad debts yield a result that specifically identifies which accounts are at risk of default.

Recall from previous discussions that credit approval may be expressed as a function of either the debtor-firm's credit score or risk of default rating. It can be said therefore that whenever a debtor-firm incurs delay in the payment of its obligations as they fall due, the debtor-firm has in fact either suffered a decline in its credit score or that its risk of default rating has risen.

Because of the limitations of current estimation techniques, reported balances of allowance for bad debts in the audited financial statements therefore cannot be relied upon to indicate the financial impact resulting from declines in credit scores of each account at risk of default as of financial reporting date.

It is therefore imperative that a more accurate estimation of allowance for bad debts (such as the one proposed by this researcher) is derived since it compels the creditor-firm to perform due diligence early enough to introduce intervention programs meant to correct the decline in credit score of the debtor-firm and to keep the debtor-firm's account current after payment update.

Mathematically, we can express the net realizable value of receivables at risk of default $\left(A R_{N R V}\right)$ as a function of the debtor-firm's outstanding balance $\left(A R_{B A L}\right)$, credit score updated $\left(C_{S}{ }^{U}\right)$ and current interest rate on loan $\left(I_{R}^{*}\right)$. That is, $A_{N R V}=f\left(A R_{B A L}, C_{S}{ }^{U}, I_{R}{ }^{*}\right)$. Given that debtor-firms who are at risk of default suffer from a decline in their credit scores, it suggests that $C_{S} *>C_{S}{ }^{U}$. Therefore, we can conclude that $A R_{B A L}>A R_{N R V}$. The difference $\left(\mathrm{AR}_{\mathrm{BAL}}-\mathrm{AR}_{\mathrm{NRV}}\right)$ represent the estimated allowance for bad debts caused by the decline in credit score of the debtor-firm. Note that in the derivation of $\mathrm{AR}_{\mathrm{NRV}}$, we assumed that creditor-firm will peg interest rate on the loan at $\mathrm{I}_{\mathrm{R}}{ }^{*}$. This assumption is being made to isolate the financial implications of the decline in credit score of the debtor-firm.

Introducing a new method to estimate allowance for bad debts using credit scores however will not be enough to solve the problem of information asymmetry since some firms may not be willing to undergo the rigid credit rating process of accredited credit rating agencies. To enforce the use of credit scores however, financial reporting standards must include its disclosure in the audited financial statements.

\section{Concluding Remarks}

The financial implications of the problem of information asymmetry can easily be measured if and when the creditor-firm is able to reliably determine which of the accounts at risk of default committed fraudulent manipulation of their credit information. This however is easier said than done since debtor-firms incur default for a variety of reasons.

Consider the case of a proprietor whose business got affected by a natural calamity. Let us assume further that the proprietor in this case suffered massive property losses as a result of the natural calamity. Naturally, the proprietor would be forced to sell whatever is left of his properties at below market value. Because the proprietor would have limited cash to spend with, he will soon be faced with choices. How do you think the proprietor will decide when 


\section{Macrothink}

International Journal of Accounting and Financial Reporting ISSN 2162-3082 2013, Vol. 3, No. 1

he is faced with a choice between paying for his basic needs and settling instalment due on his loan?

It is likewise difficult to conclude that a debtor-firm meant to defraud the creditor-firm if what ultimately caused the former to incur payment default was a controllable circumstance. A good example would be when a proprietor opted to go with marketing strategy " $\mathrm{x}$ " that resulted in very weak consumer response whereas from hindsight had the proprietor went for marketing strategy " $y$ " it would have resulted in a much stronger consumer response. How could have the proprietor known the level of consumer response for each of the marketing strategy considered?

Recall from our discussions on the problem of asymmetric information wherein it was stated that

This is because what motivates scheming debtor-firms from continuously seeking credit through fraudulent means can be explained by the principle of more is better.

What the foregoing statement translates to is that a scheming debtor-firm does what he does because he is never satisfied with what he already has. In other words, a scheming debtor-firm would want more than what he actually needs.

Mathematically, we can express this irrational behaviour for wanting more than what is needed as

$\mathbf{U}_{\mathbf{G D}}(\mathbf{N})>\mathbf{U}(\mathbf{N}, \mathbf{E})>\mathbf{U}_{\text {DD }}(\mathbf{N})$ where

$\Rightarrow \mathbf{U}_{\mathbf{G D}}(\mathbf{N})$ represents the utility derived by a good debtor-firm from what he needs $(\mathbf{N})$,

$\Rightarrow \mathbf{U}(\mathbf{N}, \mathbf{E})$ represents the utility derived from needs and wants,

$\Rightarrow \mathbf{E}$ represents excesses or wants, and

$\Rightarrow \mathbf{U}_{\mathbf{D D}}(\mathbf{N})$ represents the utility derived by a delinquent debtor-firm from what he needs $(\mathbf{N})$.

From the given equation, the good debtor-firm is not expected to want more than what he needs since he derives higher utility from what he needs compared to what he needs and wants which is $\mathbf{U}_{\mathbf{G D}}(\mathbf{N})>\mathbf{U}(\mathbf{N}, \mathbf{E})$.

Meanwhile, a delinquent debtor-firm is expected to want more than what he actually needs since he derives lower utility from his needs. Thus, the equation $\mathbf{U}(\mathbf{N}, \mathbf{E})>\mathbf{U}_{\mathbf{D D}}(\mathbf{N})$.

On account of the absence of a reasonable criteria which can be used to quantify the financial implications of the problem of asymmetric information, this research opted instead to provide creditor-firms and debtor-firms alike with the necessary tools to reduce their credit risks down to a manageable level.

In no way is it being claimed that the proposed solutions described in this research will fully resolve the problem of asymmetric information. The proposed solutions were however 
meant to take us a step closer towards achieving that goal.

\section{Acknowledgement}

I would like to express my gratitude to Dr. Ruperto Majuca, my professor in Advanced Microeconomics class for his valuable insights and suggestions.

Most importantly, I want to thank my wife, Jenalyn, my daughter, Sabrina Mae and my parents, Erlinda and Damian, who supported and encouraged me all this time despite of all the time it took me away from them.

\section{References}

LaToya, I. (2013). Credit Score. Retrieved from http://credit.about.com/od/glossary/g/creditscore.htm (April 8, 2013)

What's not in my FICO Score. Retrieved from http://www.myfico.com/CreditEducation/WhatsNotInYourScore.aspx (April 8, 2013)

The Same Rating from Different Agencies Only Looks the Same, Understanding Risk, About Moody's Ratings. Retrieved from http://www.moodys.com/ratings-process/Same-Rating-Different-Agencies-Only-Looks-the-S ame/002004002 (April 8, 2013)

Credit Rating, How it works and how to improve it. Retrieved from http://www.moneysavingexpert.com/loans/credit-rating-credit-score\#know (April 9, 2013)

Floating Interest Rate. Retrieved from http://en.wikipedia.org/wiki/Floating interest_rate (April 9, 2013)

Fixed Interest Rate. Retrieved from http://en.wikipedia.org/wiki/Fixed_interest (April 9, 2013)

Little, K. (2013). Understanding Risk, Risk and Reward are Part of Investing. Retrieved from http://stocks.about.com/od/riskreward/a/Understandrisk.htm (April 9, 2013)

Rittenberg, L., Martens, F. (2012). Enterprise Risk Management- Understanding and Communicating Risk Appetite. Retrieved from http://www.coso.org/documents/ERM-Understanding\%20\%20Communicating\%20Risk\%20 Appetite-WEB_FINAL_r9.pdf (April 9, 2013)

Valix, C. T., Peralta, J. F., \& Valix, C. A. (2012). Accounts Receivable. Financial Accounting, $1,279-280$.

Magpantay, D. D., (2013). Equivalence of the 3 Methods of Estimating Bad Debts. International Journal of Science and Research (IJSR), India Online, ISSN:2319-7064.

http://www.e-conomic.co.uk/accountingsystem/glossary/sales-turnover (April 8, 2013)

http://www.investopedia.com/terms/b/businessrisk.asp (April 8, 2013)

http://likeforex.com/glossary/w/sales-risk-46083 (April 8, 2013) 
http://www.investopedia.com/terms/c/creditrisk.asp (April 8, 2013)

http://www.ibf.ie/Libraries/Guides_Forms/Credit_Rating_Process_web.sflb.ashx (April 8, 2013)

http://www.investopedia.com/terms/d/default2.asp (April 8, 2013)

http://www.moodys.com/ratings-process/Same-Rating-Different-Agencies-Only-Looks-the-S ame/002004002 (April 8, 2013)

http://www.economicshelp.org/dictionary/a/asymmetric-information.html (April 10, 2013)

http://www.investorglossary.com/window-dressing.htm (April 10, 2013)

http://www.investopedia.com/terms/a/allowance-for-bad-debt.asp (April 10, 2013)

http://en.wikipedia.org/wiki/Experience_rating (April 10, 2013)

http://financial-dictionary.thefreedictionary.com/Net+Asset+Value (April 12, 2013)

http://www.investopedia.com/terms/l/liquidityratios.asp (April 12, 2013)

http://www.investopedia.com/terms/t/turnaround.asp (April 12, 2013)

http://highered.mcgraw-hill.com/sites/dl/free/007290027x/449880/Sample_Chapter.pdf (April 15, 2013)

\section{Glossary}

Allowance for Bad Debt: a valuation account used to estimate the portion of a bank's loan portfolio that will ultimately be uncollectible. http://www.investopedia.com/terms/a/allowance-for-bad-debt.asp

Asymmetric Information: also referred to as information asymmetry, a situation where there is imperfect knowledge. http://www.economicshelp.org/dictionary/a/asymmetric-information.html

Business Risk: the possibility that a company will have lower than anticipated profits, or that it will experience a loss rather than a profit. http://www.investopedia.com/terms/b/businessrisk.asp

Credit Rating: a formal evaluation of an individual's or a company's credit history and ability to repay obligations. http://www.ibf.ie/Libraries/Guides_Forms/Credit_Rating_Process_web.sflb.ashx

Credit Risk:the risk of loss of principal or loss of a financial reward stemming from a borrower's failure to repay a loan or otherwise meet a contractual obligation. http://www.investopedia.com/terms/c/creditrisk.asp

Credit Score: a numerical summary of the information contained in ones credit report. http://credit.about.com/od/glossary/g/creditscore.htm

Default: the failure to promptly pay interest or principal when due. 


\section{Macrothink \\ International Journal of Accounting and Financial Reporting \\ ISSN 2162-3082 2013, Vol. 3, No. 1}

http://www.investopedia.com/terms/d/default2.asp

Experience Rating: a method used by insurers to determine pricing of premiums for different groups or individuals based on the group or individual's history of claims. http://en.wikipedia.org/wiki/Experience_rating

Information Asymmetry: See Asymmetric Information

Liquidity Ratio: a class of financial metrics used to determine a company's ability to pay off its short-term debts and/or obligations. http://www.investopedia.com/terms/l/liquidityratios.asp

Net Asset Value: the value of the company's assets minus the value of its liabilities. http://financial-dictionary.thefreedictionary.com/Net+Asset+Value

Net Realizable Value: the amount of cash expected to be collected or the estimated recoverable amount. (FINANCIAL ACCOUNTING Volume One 2012 Edition, Conrado T. Valix, Jose F. Peralta and Christian Aris M. Valix)

Risk Appetite: the amount of risk, on a broad level, an organization is willing to accept in pursuit of value. http://www.coso.org/documents/ERM-Understanding\%20\%20Communicating\%20Risk\%20 Appetite-WEB_FINAL_r9.pdf

Sales Risk: the uncertainty with respect to the quantity of goods and services that a company is able to sell and the price it is able to achieve. http://likeforex.com/glossary/w/sales-risk-46083

Sales Turnover: the value of goods and services provided to customers during a specified time period usually one year. http://www.e-conomic.co.uk/accountingsystem/glossary/sales-turnover

Turnaround: the financial recovery of a company that has been performing poorly for an extended time. http://www.investopedia.com/terms/t/turnaround.asp

Window Dressing: an assortment of alterations a bookkeeper might make to a financial statement, whether legal or illegal, so that the statement appears stronger than it is. http://www.investorglossary.com/window-dressing.htm

\section{Copyright Disclaimer}

Copyright reserved by the author.

This article is an open-access article distributed under the terms and conditions of the Creative Commons Attribution license (http://creativecommons.org/license/by/3.0/). 